\title{
Forma y obra arquitectónica en la proyección y acontecimiento del paisaje arquitectónico
}

\section{Form and architectural work in the projection and occurrence of architectural landscape}

\author{
Edwin Quiroga Molano*
}

Citar este artículo como: Quiroga, E. (2016). Forma y obra arquitectónica en la proyección y acontecimiento del paisaje arquitectónico. Revista nodo, 11(21), 79-94.

\section{Resumen}

La arquitectura debe considerar su condición como obra de arte a fin de trascender el carácter contingente del objeto arquitectónico. Al respecto, la presente investigación discute el hacer y el fabricar como relaciones externas mediadoras entre la arquitectura y el paisaje. En oposición, se propone el acontecimiento poiético mediante el que la arquitectura se instaura como obra de arte. Tal planteamiento se analizó en obras arquitectónicas y quedó demostrado mediante el acontecimiento por el cual se revela el paisaje.

Palabras clave: Naturaleza, Paisaje, Composición, Determinación formal, Forma arquitectónica, Obra arquitectónica, Poiesis.

\begin{abstract}
Architecture must consider its condition as a work of art to transcend the contingent character of the architectural object. In this respect, current inves-
\end{abstract}

tigations discuss the making and the manufacture as mediating external relations between the architecture and landscape. In opposition, the poietic befall arises through which architecture is established as a work of art. This approach was analyzed in architectural works and was demonstrated by the event in which the landscape is revealed.

Keywords: Nature, Landscape, Composition, Formal determination, Architectural form, Architectural work, Poiesis.

\section{Introducción}

El tema de la presente investigación ${ }^{1}$ trata sobre la obra arquitectónica y su relación con el paisaje arquitectónico. Aquí la noción de obra arquitectónica parte de lo planteado para su época por Adolf Loos, quien quiso comprender el estatus de la arquitectura en torno a las discusiones entre artesanía, industria y arte para con la arquitectura (Loos, 1993). Dicha distinción, lleva a Loos a vincular parte de la arquitectura con el arte para,

Fecha de recepción: 15 de junio de 2016 • Fecha de aceptación: 7 de agosto de 2016

\footnotetext{
* Arquitecto, magíster en Arquitectura. Docente investigador de la Universidad Piloto de Colombia. Contacto: edwinquiroga@unipiloto.edu.co

1 Se desarrolló en el marco del proyecto de investigación "El concepto de paisaje en el aprendizaje de la composición arquitectónica" de la Línea de Investigación "Proyecto: Teorías, Métodos y Prácticas" y al grupo de investigación "HD+i" de la Universidad Piloto de Colombia, con la participación del director de la Línea de Investigación, M. Arq. Plutarco Rojas Quiñones y el docente investigador M. Arq. Rafael Francesconi Latorre.
} 
desde allí, homologar la obra arquitectónica con la obra de arte. Para Loos, el arte no debe considerar ningún uso práctico, todo lo que sirve a un fin debe ser excluido del arte.

Esta consideración inicial permite comprender que la relación entre la obra arquitectónica y el paisaje debe sobrepasar un fin de carácter netamente transitorio. No obstante, la arquitectura deja de lado tal consideración, de ahí el cuestionamiento que Loos hace en la manera en que el arquitecto se relaciona con el paisaje:

Y por ello pregunto: ¿cómo es que todo arquitecto, bueno o malo, deshonra el lago? El campesino no lo hace. Tampoco el ingeniero que construye un ferrocarril en la orilla o que traza con su barco profundos surcos en el claro espejo del lago. Ellos crean de otra manera. [...] (Loos, 1993, p. 23).

Más adelante, Loos señala el descenso de la arquitectura hasta el arte gráfico. Es por esto que el problema enunciado en la interpelación anterior, entre la arquitectura y el paisaje, se pueda comprender como una relación netamente externa y de apariencia, conllevando a una coexistencia contradictoria entre arquitectura y paisaje.

Dicho conflicto ha dado paso, por una parte, al reconocimiento de leyes autónomas de formación por separado para la arquitectura y el paisaje, que conducen a posiciones aisladas e independientes entre sí. Del otro extremo, la constitución y los principios de la arquitectura y el paisaje se confunden y entremezclan, dando origen a artificios híbridos ininteligibles como pretextos azarosos de la realidad.

Por lo anterior, y para dejar de lado posturas polarizadas o combinaciones aleatorias entre arquitectura y paisaje, resulta importante dar respuesta a la coexistencia contradictoria entre la arquitectura y el paisaje, en el sentido de identificar los principios constitutivos de estos, mediante los que se establezcan relaciones entre sí, como lo sugiere parte de la comunidad académica al considerar que "[...] la arquitectura no tiene porqué confundirse con la vida ni con el sitio ni con las técnicas materiales. Basta que consiga establecer con ellos unas correspondencias o relaciones [...]" (Armesto, p. 35).

Ahora bien, en cuanto al problema en mención, surge la pregunta: ¿qué permite resolver el conflicto entre la arquitectura y el paisaje? Parte de la respuesta se encuentra en la distinción que hace Adolf Loos sobre la arquitectura, en donde, además de manifestar una relación con el paisaje mediante la "creación" del campesino y del ingeniero, abre una tercera relación: la obra de arte. Esta última se comprende como una relación interna entre la arquitectura y el paisaje, distinta al hacer del campesino y a la ciencia del ingeniero, quienes establecen una relación externa con el paisaje.

Por lo anterior, a modo de hipótesis, se sostiene que la respuesta al conflicto entre la arquitectura y el paisaje, se encuentra en la dialéctica interna de la arquitectura: en la obra de arte, entendida como el acontecimiento mediante el cual se revela algo (Heidegger, 2010).

Según la hipótesis, el presente artículo tiene por objeto el estudio de obras arquitectónicas que revelen, para este caso, el paisaje, siendo importante aclarar en qué sentido las obras analizadas revelan el paisaje. Por lo anterior, y para lograr dicho aporte, se trata de una investigación de carácter explicativa (Escorcia, 2010), partiendo de la hipótesis anteriormente formulada. Por otra parte, se hizo necesario precisar el concepto de forma arquitectónica en relación con obra arquitectónica, estudiar la manera en que acontece el paisaje en la obras arquitectónicas seleccionadas, así como comprender los fundamentos analíticos y teóricos que permitieron orientar la interpretación de la obra arquitectónica en relación con el paisaje.

\section{Metodología}

La investigación pone a consideración la aproximación y discusión teórica, así como la presentación de casos de estudio. La discusión se centra en la revisión teórica sobre el hacer, el producir y 
el acontecimiento mediante el cual se revela el paisaje, este último, propio de la obra de arquitectónica. En cuanto al estudio de los casos de estudio, la investigación dio cuenta de la manera en que se revela el paisaje arquitectónico mediante el análisis de obras arquitectónicas.

Los casos de estudio presentados fueron seleccionados por ser considerados obras arquitectónicas paradigmáticas e instaurar relaciones con el paisaje. Cada obra mantiene una caracterización propia de relación con el paisaje a partir de su estructura de recorrido y contemplación: la marche, la promenade architectural y la errancia. El análisis es inductivo con respecto a las formas y relaciones de las obras con el paisaje, y deductivo por la formulación y verificación de hipótesis, dadas durante el análisis y comparadas en relación con los caso de estudio y con el componente teórico.

\section{El hacer, el fabricar y el acontecer del paisaje}

El presente estudio parte de las reflexiones de Kenneth Frampton (2012), quien actualiza la distinción entre el carácter de la construcción vernácula y la arquitectura, inicialmente propuesta por Adolf Loos (1993). La lectura de la condición humana de Hannah Arendt, especialmente los conceptos trabajo, labor y acción; constituye uno de los principales puntos de referencia para la distinción de la arquitectura. A partir de allí, Kenneth Frampton (2012) resalta la dualidad del homo faber, entre la fabricación de obras de arte y de utensilios. La anterior acotación lleva a estudiar la diferenciación entre forma y obra. En cuanto a la forma, se hace una revisión de las nociones de determinación formal y composición planteados por Giulio Carlo Argan (1984). En cuanto a la obra, se hace la revisión sobre el concepto de obra de arte acotados por Martin Heidegger (2010). Las aproximaciones al concepto de forma y de obra conllevan a conciliar la relación entre la arquitectura y el paisaje, la primera desde el campo metafísico y la segunda desde el área ontológica.
A la noción de paisaje antecede la noción de naturaleza, es a partir de allí que esta última es modificada bajo la intervención del hombre, teniendo como resultado la alteración de sus principios constitutivos:

El paisaje es así el efecto de la superposición de la
actividad de la vida humana sobre la naturaleza,
[...] e incluye las modificaciones derivadas
de la actuación sobre el medio para hacerlo
productivo [...] y construir artificialmente sobre
él, sean infraestructuras [...] o realizaciones
propiamente arquitectónicas (Abalos, 2005,
p. 42).

Parte de las intervenciones generadas sobre la naturaleza son acotadas por Adolf Loos, en la distinción que hace sobre arquitectura en el documento Architektur, 1910 (1993), en donde el autor manifiesta tres posibles maneras de intervenir la naturaleza y que en relación con el hecho resultado de las intervenciones sobre la naturaleza, se tendría: la modificación del campesino mediante el hacer, la del ingeniero a través de fabricación y la del arquitecto mediante la arquitectura.

Ahora bien, Adolf Loos, además de definir tres distintas maneras de intervenir, considera que la diferencia del proceder entre el arquitecto y el campesino se debe a la cultura que este último posee, entendiendo la cultura como "[...] la armonía entre el hombre interior y exterior, y solo es garantía de un pensar y actuar sensatos [...]" (Loos, 1993, p. 24). Aquí el concepto de cultura más que ser preeminente del campesino, de igual manera hace parte del ingeniero y del arquitecto, aunque de manera distinta. La cultura de cada uno está basada en condiciones que definen la manera de proceder, para este caso, ante la naturaleza.

La distinción entre el campesino, el ingeniero y el arquitecto, lleva a establecer relaciones con las actividades de la condición humana: labor, trabajo y acción (Arendt, 2009). La primera, una práctica irreflexiva, un estado connatural e inmanente de la vida; la segunda, una praxis reflexiva, un estado cognitivo productivo; y una tercera, en relación con el pensamiento, un estado de juicio y crítica en 
torno al arte. Es por esto que el arquitecto va en contravía del "hacer" del campesino y al producir del ingeniero, en la naturaleza. Dichas concepciones, si bien son distantes, son complementarias a la vez.

De las anteriores posturas, el trabajo, y con éste, la actividad del ingeniero, tras la lectura de la condición humana (Arendt, 2009), Kenneth Frampton (2010) acentúa la dualidad que emerge en el trabajo del homo faber, entre la fabricación de objetos inútiles, como la obras de arte, con un fin en sí mismo; y de objetos útiles, como los utensilios, con un fin específico'. Un desplazamiento del "qué" al "cómo", en palabras de Hannah Arendt, y que Frampton ve manifestado en la separación entre la ingeniería y la arquitectura en el periodo de la ilustración.

Esta dualidad del homo faber sucede de igual manera en la arquitectura y su contexto. Dicotomía que puede ser considerada en el estudio que Giulio Carlo Argan (1984) realiza entre el tránsito de la arquitectura del renacimiento, con la determinación formal del espacio, a la arquitectura del barroco, con la composición del espacio ${ }^{2}$. La determinación formal, además de ser considerada como una labor, "un proceso vital, un proceso de vida" (p. 19), se establece como un trabajo mediante el cual se hace y se determina las propias formas arquitectónicas. La composición, si bien es un trabajo que re-presenta las formas arquitectónicas a partir de formas preestablecidas, lo hace mediante una reflexión, siempre cambiante, fundamentada en premisas teóricas.

si consideramos entonces estas dos posiciones como diametralmente opuestas, veremos que la

$1 \quad$ Si bien, las reflexiones de Kenneth Frampton, sobre la obra de arte y el utensilio, devienen de los planteamientos de Hannah Arendt (2009), estas son comparables a las distinciones de Martin Heidegger, en tanto, "la obra no es un utensilio dotado de un valor estético añadido. La obra no es eso en la misma medida en que la mera cosa no es tampoco un utensilio al que sólo le falta lo que constituye el auténtico carácter de utensilio: la utilidad y la elaboración" (Heidegger, 2010, p. 27).

2 La distinción entre determinacional formal y composición ha sido estudiada en relación con el proyecto arquitectónico y su emplazamiento en Correal et al. (2015). posición del hombre del sistema es una posición contemplativa y la posición del hombre del hacer o del hombre del método es una posición activa. [...] Para el hombre del sistema, para el hombre contemplativo, el espacio es un dato revelado (Argan, 1984, p. 21).

Aunque para este caso la posición contemplativa se da en la noción metafísica ${ }^{3}$, dicha posición debe ir más allá de la forma $a^{4}$ para ser considerada desde la dialéctica interna de la arquitectura. Se propone que la contemplación surja en la obra arquitectó$n i c a^{5}$. Es allí donde en respuesta al conflicto entre arquitectura y paisaje, se establece una relación fundada a partir de un fin interno.

Pero la obra de arte, en cambio, no debe quedar deteriorada por el uso. Es eterna. No debe servir para ningún uso práctico, a fin de no perder nada de su valor. Debe tener tiempo necesario para cumplir su misión. Debe durar hasta que, por su misión continuada, se haya impuesto

3 "El pasaje de una posición contemplativa a una posición activa será también el pasaje de una concepción metafísica a una concepción social del espacio (Argán, 1984, p. 21). Como lo sugiere Argan, aquí la contemplación, participa en el proceso de composición, fundamentada en la metafísica, es decir, en principios predeterminados sobre elementos racionalmente relacionados entre sí a través de la forma y su materialización. En cuanto a este asunto, Martin Heidegger rechaza la metafísica para aprender a mirar más allá de las cosas, con el fin de aproximarse a la esencia, que no radica precisamente en lo universal. Se deja de lado la lógica, las cosas no deben ser preconcebidas desde un concepto. "La diferenciación entre materia y forma es el esquema conceptual por antonomasia para toda estética y teoría del arte bajo cualquiera de sus modalidades. Pero este hecho irrefutable no demuestra ni que la diferenciación entre materia y forma esté suficientemente fundamentada ni que pertenezca originariamente al ámbito del arte y de la obra de arte." (Heidegger, 1935/2010, p. 18).

$4 \quad$ En cuanto a la forma, "[...] la palabra forma se aproxima más al que recibe en la metafísica, donde la forma se opone a la materia, siendo la materia aquello con lo cual se hacen las cosas y la forma aquello que determina la materia para que las cosas sean lo que son. [...], es decir, de los que es susceptible de análisis y de conocimiento. [...] (Martí, 1993, pp. 83-86).

5 Martin Heidegger considera que "el acontecimiento de la verdad forma parte de la esencia de la obra" (1935/2010, p. 41). 
a los hombres. Nunca se volverá fea, nunca ha sido hermosa (Loos, Arte y Arquitectura (1920), 1993, p. 159).

La obra, como lo sentencia Adolf Loos, no debe servir a un uso práctico, lo que sirve a un fin debe quedar excluido del arte, "la arquitectura es un arte" (Loos, 1910/1993), y como tal debe corresponder a un fin interno. Desde la obra arquitectónica es preciso que la arquitectura establezca relaciones con el paisaje. Cuando se aleja de allí, para responder a fines externos, el arquitecto bueno o malo deshonra el paisaje.

A continuación, mediante el análisis de obras arquitectónicas se estudia la manera en que acontece la revelación del paisaje en la arquitectura.

\section{Proyección y acontecimiento del paisaje arquitectónico}

Los proyectos que a continuación se analizan permiten comprender que la forma arquitectónica dispone sus partes y relaciones según el estatus ontológico de la arquitectura, a saber, el acontecimiento del paisaje en la obra arquitectónica. Como ejemplificación se recurre al análisis de proyectos en relación con los conceptos de marche, promenade architecturale y errancia, tres conceptos que sibien presentan diferencias de grado, se establecen como estructuras de relación en la formalización de la naturaleza como paisaje arquitectónico. Cada uno de estos análisis es considerado desde su estructura de recorrido y contemplación, estudiado en relación con: la aproximación, el acceso, el tránsito (Ching, 2002), y el culmen.

\section{Marche}

Esta estructura de recorrido característica de espacios como la Ópera Garnier, en sugerencia de Leupen (1999), alcanza una sublime teatralidad en la escalera donde la direccionalidad horizontal y lineal se rompe, para dar paso a un espacio sinuoso en ascenso y a la vez culmen del recorrido en donde se desarrolla la verdadera actividad de la ópera: el encuentro social.
El pintoresquismo inglés tiene una influencia especial en el tratamiento del recorrido secuencial instaurado en la Ópera. La característica de la marche es el desarrollo que manifiesta el recorrido en el interior del edificio, conllevando a la vivencia del espacio interior (Leupen, 1999). Aquí el edificio niega las relaciones con el espacio exterior. Como ejemplificación de este modo de operar se recurre a la casa pompeyana, en particular la casa del fauno.

Ahora bien, esta concepción entorno a la naturaleza, permite formalizar la casa entorno a cuatro estructuras centralizadas. La primera de ellas entorno al atrium, la segunda entorno al Tetrastile (espacio de cuatro columnas), la tercera y cuarta alrededor de los Viridarium (jardín) central y posterior de la casa. Estas estructuras centralizadas, a su vez, son ordenadas axialmente, en particular, el atrium y los dos Viridarium (jardín) central y posterior.

La casa está conformada por:

(1) Fauses -vestíbulo

(A) Impluvium

(A') Atrium

(2) Alae - pasillo

(3) Tablinum - sala

(4) Triclinium - comedor

(5) pasillo-tránsito

(A) Tetrastile (espacio de cuatro columnas)

(B') Tetrastile atrium

(C) Viridarium (jardín)

(C') Peristilium del viridarium

(6) Exedra

(7) Triclinium - comedor

(8) Pasillo-tránsito

(D) Viridarium (jardín)

(D') Peristilium del viridarium

El emplazamiento de la casa del fauno ocupó la totalidad de la manzana, no obstante, su relación con las cuatro calles que lo paramentan es delimitada. Solo el lado de la casa por el que se accede, se relaciona con la calle mediante actividades 
comerciales autónomas y sin relación directa con respecto a la casa.

La aproximación a la casa del Fauno se hace mediante las calles de su entorno, aquí la aproximación hacia el acceso se da por la vía della fortuna, vía que hace parte del eje de la Porta di Nola, siendo ésta, una de las entradas a la ciudad. El acceso a la casa se da a través de las fauses -vestíbulo- (1), un espacio que media la relación entre el exterior y el interior de la vivienda, entre lo público y lo privado. Para la casa del fauno, si bien tiene dos entradas, la principal es el atrium (A) sobre la que reposa la escultura del fauno. Desde el vestíbulo, la percepción de la casa se abre de modo continuo en dirección de los distintos espacios abiertos de la casa. El tránsito está conformado por una secuencia de recintos y porches, en este recorrido, la percepción dinámica -recorrido-y la percepción estática-permanencia-, no mantienen el mismo trayecto, se relacionan de una manera especial.
La Percepción estática -permanencia-, sucede con el mismo orden axial en que se estructura la casa, la percepción es continua. Desde el vestíbulo de entrada la mirada sobrepasa el atrium, el viridarium central, para terminar en el viridarium posterior de la casa; aquí, a través de la percepción, los distintos espacios son concatenados. Luego, en cada uno de los recintos en mención, es posible tener una relación visual continua hacia los otros recintos de la casa, como sucede cuando se está en algunas de las estancias de permanencia, como el tablinum - sala (3), el triclinium - comedor (4) y/o la exedra principalmente (Ver imagen 1,2).

A su vez, la percepción dinámica -recorridocontrario a ser axial, se genera por una alternancia, entre recorridos frontales, laterales y deambulatorios (ver imagen 3,4).

Por la misma conformación de la casa, La percepción estática -permanencia- es continua, complementada con la percepción dinámica -

Imágenes 1 y 2. Casa del Fauno. Percepción estática-permanencia-.

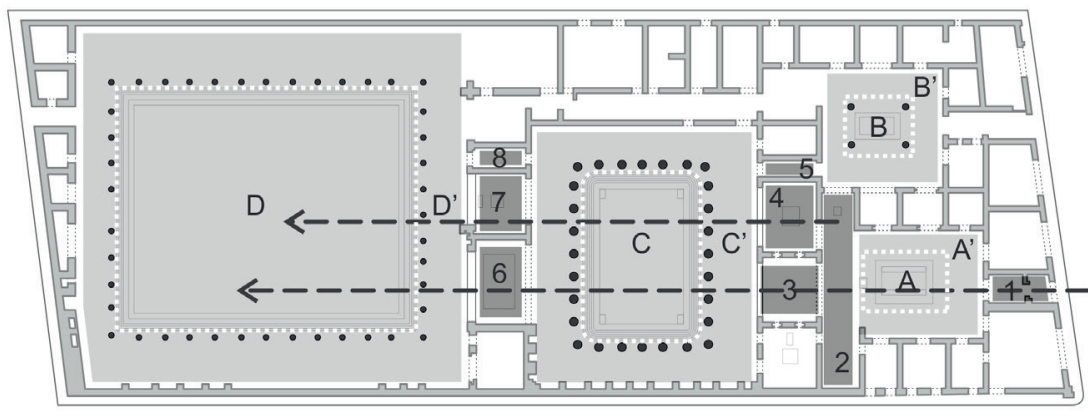

Fuente: el autor (análisis), Andrés Ortiz (redibujo), 2016.

Imágenes 3 y 4. Casa del Fauno. Recorrido a través de los recintos.

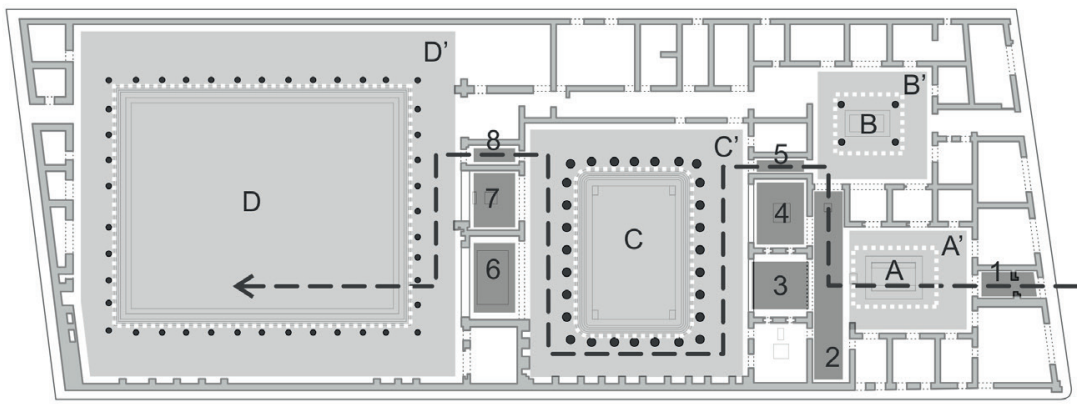

Fuente: el autor (análisis), Andrés Ortiz (redibujo), 2016.
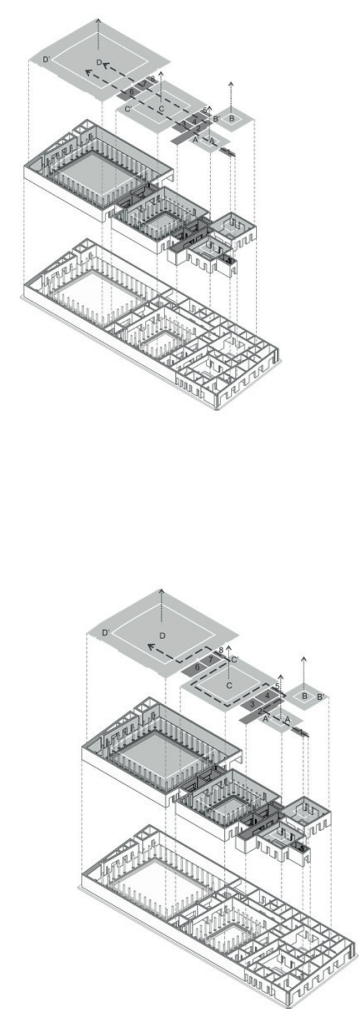
Imágenes 5, 6, 7, 8, 9, 10, 11, 12 y 13. Casa del Fauno. Percepción durante la marche.

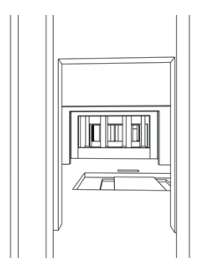

(1) Fauses -vestíbulo

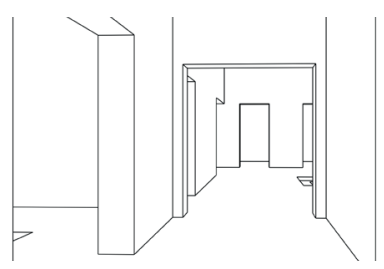

(2) Alae - pasillo

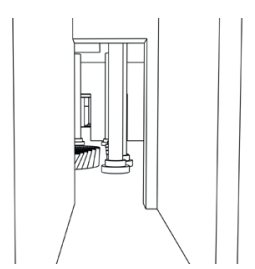

(8) Pasillo-tránsito

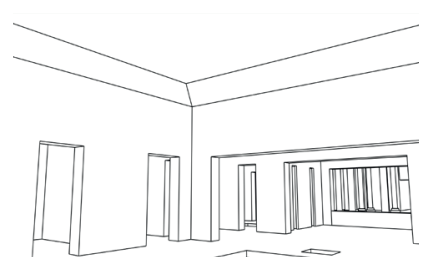

(2) Impluvium

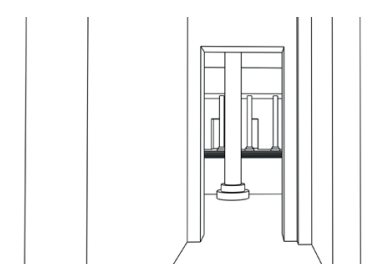

(5) pasillo-tránsito

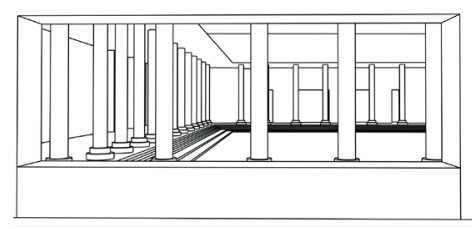

(6) Exedra

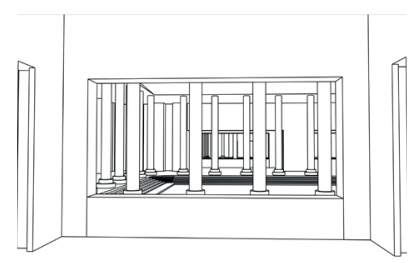

(3) Tablinum - sala

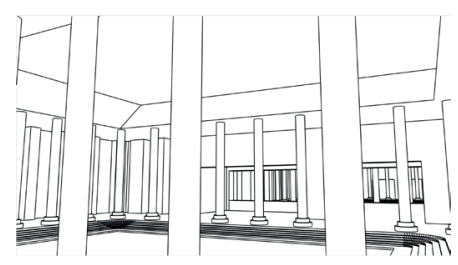

(C) Viridarium (jardín)

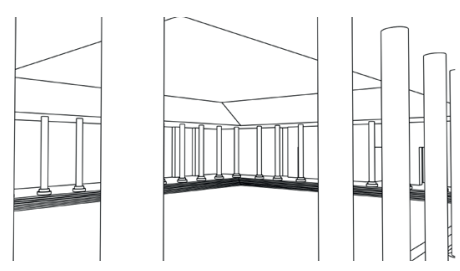

(D) Viridarium (jardín)

Fuente: el autor (análisis), Andrés Ortiz (redibujo), 2016.

recorrido- en el que sucede un recorrido frontal, lateral y "entorno a". A continuación, se presentan las distintas escenas percibidas durante el recorrido y las permanencias de la casa:

Si bien, las distintas relaciones sociales, privadas y/o públicas, vaticinaban hasta donde era el acceso de las personas y con ello el culmen de su estancia en la casa, la cualidad espacial en el que se dispone la naturaleza, hace que cada uno de estos lugares, sea un lugar por contemplar, de ahí el fuerte simbolismo que se lograba en cada uno de estos. Por lo anterior, no es preciso hablar de un solo culmen en la casa del fauno, cada uno de los recintos abiertos, el atrio, o los viridarium central y/o posterior, cada espacio de estos en los que la naturaleza se formaliza en jardín, son cúlmenes en el proyecto, en cada uno de ellos es posible contemplar la naturaleza transformada en jardín.

\section{La promenade architecturale}

Entendida como un tránsito en el espacio, que a diferencia de la marche, se constituye como un elemento en relación con los demás espacios interiores pero autónomo, permite establecer, "una percepción continuada, manteniendo la mirada fija en el objeto que nos atrae" (Quetglas, 2004, p. 205).

Le Corbusier lleva la cualidad espacial de la promenade architectural a varios de sus proyectos, entre estos la casa la Roche 1923-1925 (Le Corbusier, 1937, p. 60), la Casa Curutchet 1949-1953 (Le Corbusier, 1949) y la Villa Savoye 1929, en la que enuncia las características del recorrido en relación con el paisaje.

Del interior del vestíbulo arranca una rampa suave que nos conduce, casi sin darnos cuenta, al primer piso, en donde transcurre la vida de 
los habitantes: la recepción, los dormitorios, etcétera. Tomando vista y luz del contorno regular de la caja, las diferentes habitaciones van a juntarse, radiando, a un jardín suspendido [...].

Del jardín suspendido, la rampa, que ahora es ya exterior, conduce al tejado, al solárium (Le Corbusier, 1978, p. 158).

Si bien, la anterior descripción sobre la Villa Savoye presta atención al tránsito y culmen del recorrido en la vivienda, se hace necesario hablar de otros dos aspectos que hacen parte de dicho tránsito, como lo son la aproximación y el acceso.

La aproximación a la vivienda (ver imágenes 14 y 15), depende del emplazamiento de la vivienda en el lugar, para este caso la vivienda se ubica en el claro de un bosque. El paseante atraviesa una masa de árboles que definen el recinto natural en el que es emplazada la vivienda, caracterizando de este modo la vivienda por tener un posicionamiento por inclusión; al tiempo que se percibe la vivienda se establece una conexión vertical con el cielo. Una vez en el recinto natural, la percepción

Imágenes 14 y 15. Villa Savoye - Le Corbusier. Promenade architecturale - aproximación.

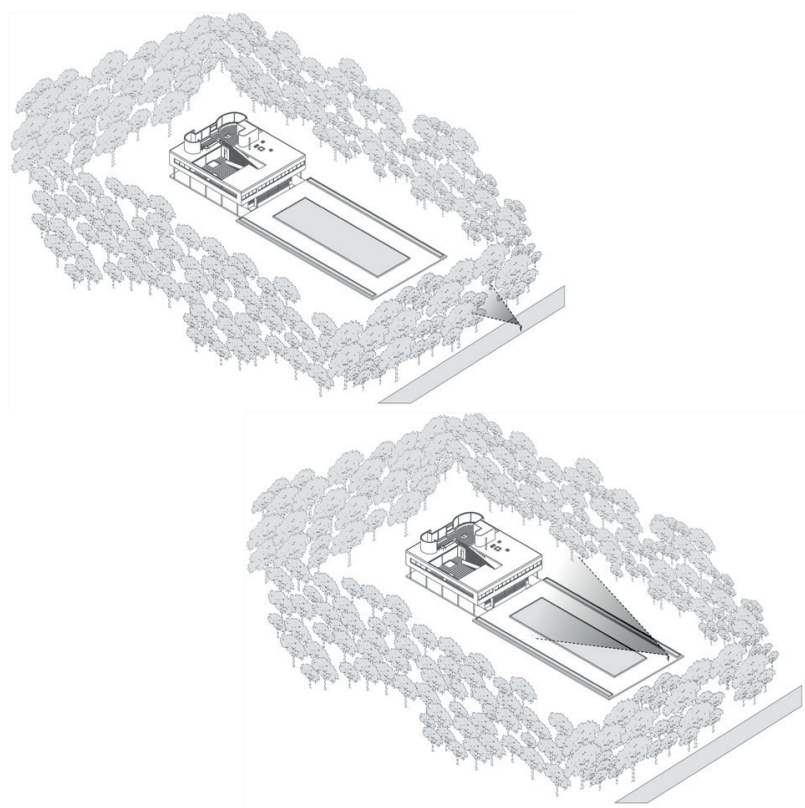

Fuente: el autor (análisis), Hugo Martínez (redibujo), 2016. hacia la vivienda es frontal y su aproximación continúa por un camino lineal compartido por el recorrido en vehículo.

El acceso a la vivienda inicia con la articulación entre el camino lineal y el porche perimetral que se conforma en el primer nivel, estableciendo una relación horizontal con el límite -árboles- del recinto natural (ver imágenes de la 16 a la 19).

Imágenes 16, 17, 18 y 19. Villa Savoye - Le Corbusier. Promenade architecturale - acceso.
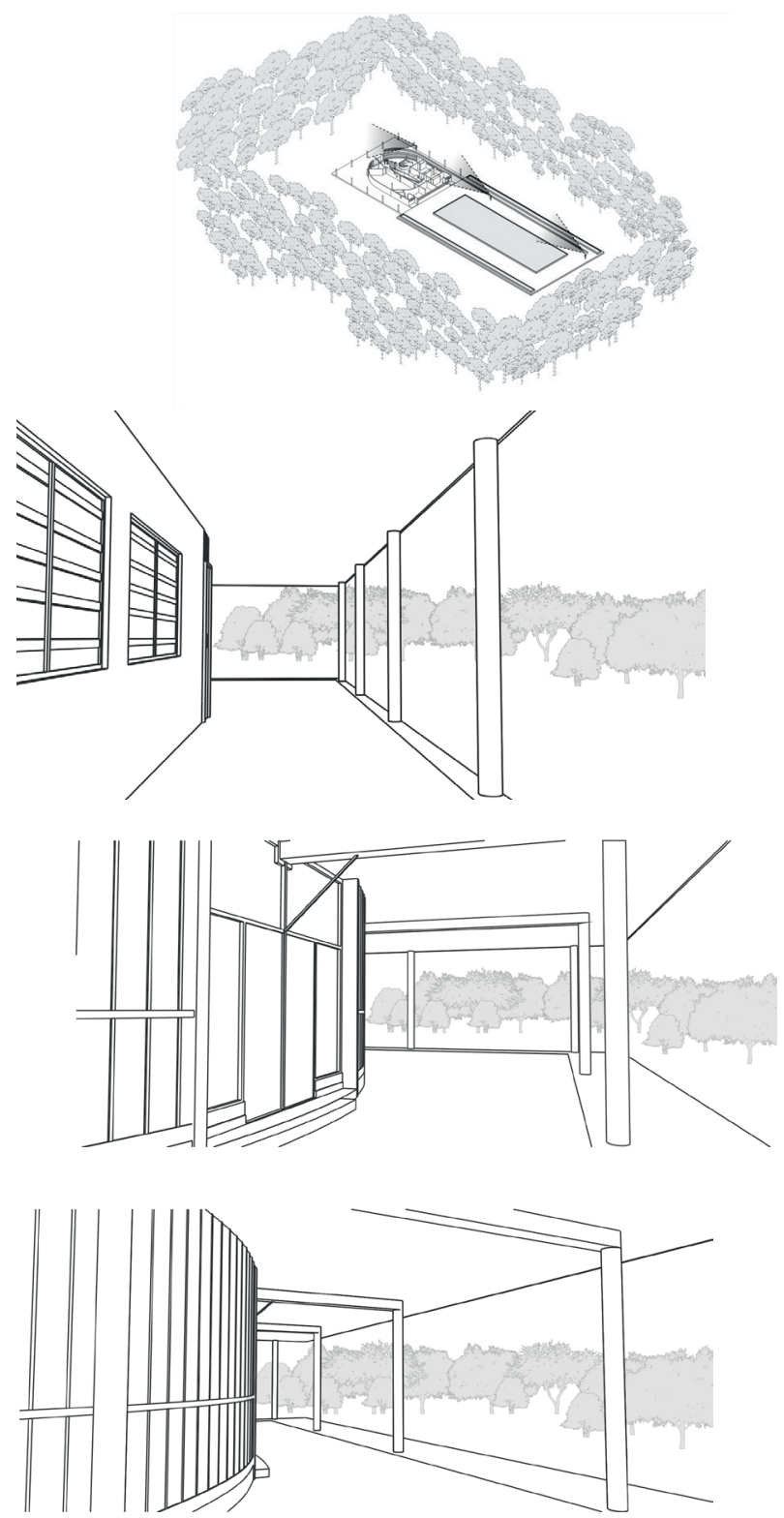

Fuente: el autor (análisis), Hugo Martínez (redibujo), 2016. 
El tránsito por el proyecto, como ya fue mencionado en la cita de Le Corbusier, inicia en el vestíbulo enmarcado por cuatro columnas, allí se tiene la elección de tomar la escalera o la rampa, ambas conducen a la terraza -solárium- (ver imágenes 20 y 21).

Imágenes 20 y 21. Villa Savoye -Le Corbusier. Promenade architecturale- Tránsito vestíbulo.
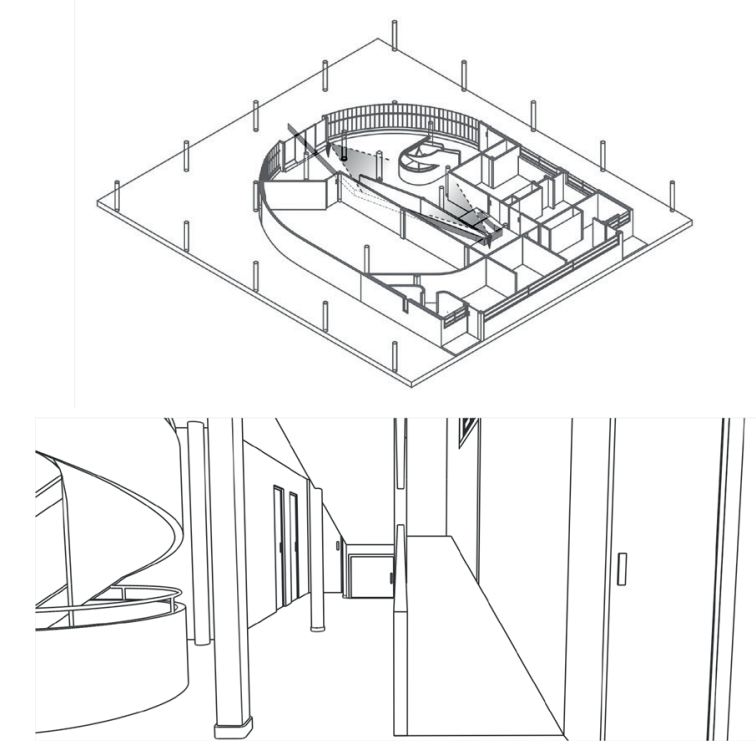

Fuente: el autor (análisis), Hugo Martínez (redibujo), 2016.

El tránsito en la rampa comprende una secuencia de espacios, en el recorrido del primero al segundo nivel se asciende por un espacio controlado horizontal y verticalmente, la luz y sombra acompañan este primer tránsito (ver imagen 22).

Imágenes 22. Villa Savoye - Le Corbusier. Promenade architecturale - Tránsito rampa.

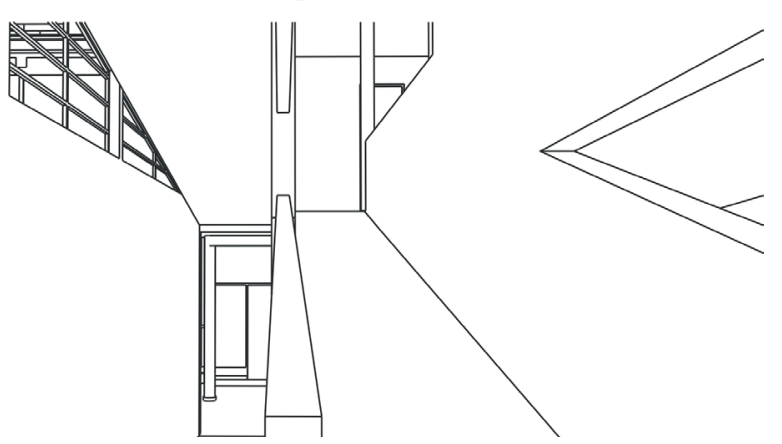

Fuente: el autor (análisis), Hugo Martínez (redibujo), 2016.
El segundo tránsito del recorrido se da en el patio -jardín suspendido- del segundo nivel (primer piso para Le Cobusier) definido en tres de sus cuatro lados por distintos espacios, el cuarto lado del patio está definido por el muro con "ventana corrida" que bordea la vivienda, aquí la ventana corrida de este muro "enmarca" el paisaje natural inmediato dado por el límite del recinto natural. En este patio se encuentran dos jardineras que le dan el carácter de "jardín suspendido" junto con la percepción del paisaje que se tiene a través de la ventana corrida, aquí la naturaleza exterior de igual manera es domesticada mediante el "enmarque" (ver imágenes 23 y 24).

Imágenes 23 y 24. Villa Savoye - Le Corbusier. Promenade architecturale - Tránsito "jardín suspendido".
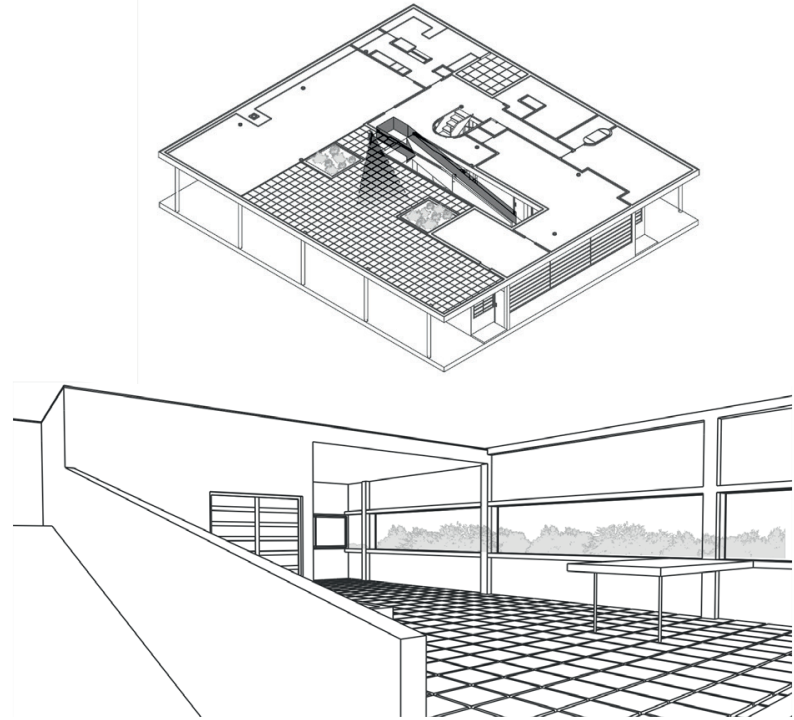

Fuente: el autor (análisis), Hugo Martínez (redibujo), 2016.

El tercer tránsito del recorrido inicia en el patio en mención, aquí ya la rampa es abierta y a medida que se asciende al solárium se va teniendo percepción del paisaje natural (ver imágenes 25 y 26).

El culmen de la vivienda se da en la cubierta del segundo nivel conformada por una terraza superior, siendo delimitada solo en uno de sus cuatro lados por un muro y en el que se abre un vano para enmarcar el paisaje natural inmediato que 
Imágenes 25 y 26. Villa Savoye - Le Corbusier. Promenade architecturale - Tránsito acenso "solárium".
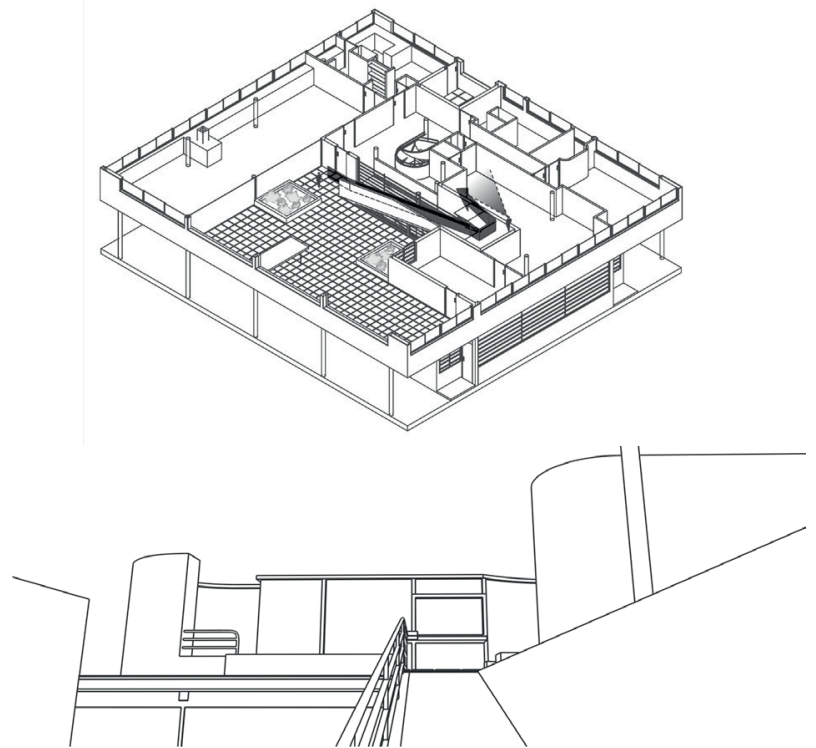

Fuente: el autor (análisis), Hugo Martínez (redibujo), 2016.

delimita el contexto de la vivienda. El solárium al que hace referencia Le Corbusier, puede referirse específicamente al espacio que se conforma por el vano del muro, en el que se dispone una superficie horizontal a modo de mesa. Las jardineras realizadas en la base del muro y las dos laterales que terminan por conformar el espacio del solárium. Este espacio también puede considerarse como un vestíbulo exterior, un espacio antesala que establece una relación con el paisaje. Recuerda el vestíbulo de acceso a la casa, enmarcado por las cuatro columnas (ver imágenes de la 27 a la 29).

En este último espacio también hace presencia el jardín suspendido del segundo nivel, un espacio que además de enmarcar el paisaje natural, lo contrasta con el paisaje domesticado de la vivienda, el jardín.

La casa se compone por distintas partes, entre las principales, se encuentra el volumen de acceso en torno al cual se disponen columnas a modo de perístasis de los templos griegos; el patio -jardín suspendido-, alrededor del cual se disponen los espacios del segundo nivel de la vivienda; el solárium, dispuesto en la cubierta del segundo nivel;
Imágenes 27, 28 y 29. Villa Savoye - Le Corbusier. Promenade architecturale - Culmen "solárium".
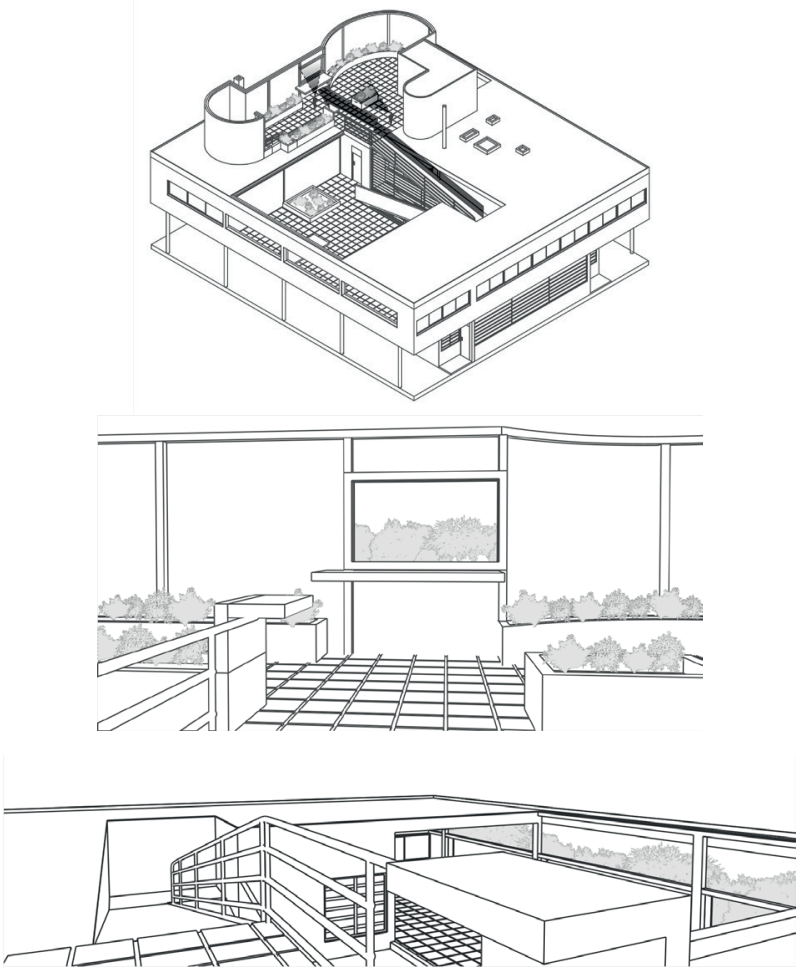

Fuente: el autor (análisis), Hugo Martínez (redibujo), 2016.

y por último, se encuentran los elementos de la circulación, la rampa y la escalera; elementos que encadenan los distintos ámbitos de la casa.

\section{Errancia arquitectónica}

La errancia, termino asociado a la obra de Rogelio Salmona. Asume las características de la marche y de la promenade architectural. A continuación se analiza el edificio de Posgrados de la Universidad Nacional de Colombia obra de Rogelio Salmona.

El emplazamiento del edificio es exento en un solar delimitado por árboles, dicho emplazamiento, entre otros aspectos, conforma un recinto natural posterior y anterior. Este último, permite generar un tránsito con el campus universitario, aquí es donde inicia la aproximación al edificio acentuada por un recorrido paralelo a la fila de árboles del lado oriental del recinto natural (ver imágenes 30 y 31$)$. 
Imágenes 30 y 31. Edificio de Posgrados - Rogelio Salmona. Errancia - aproximación.

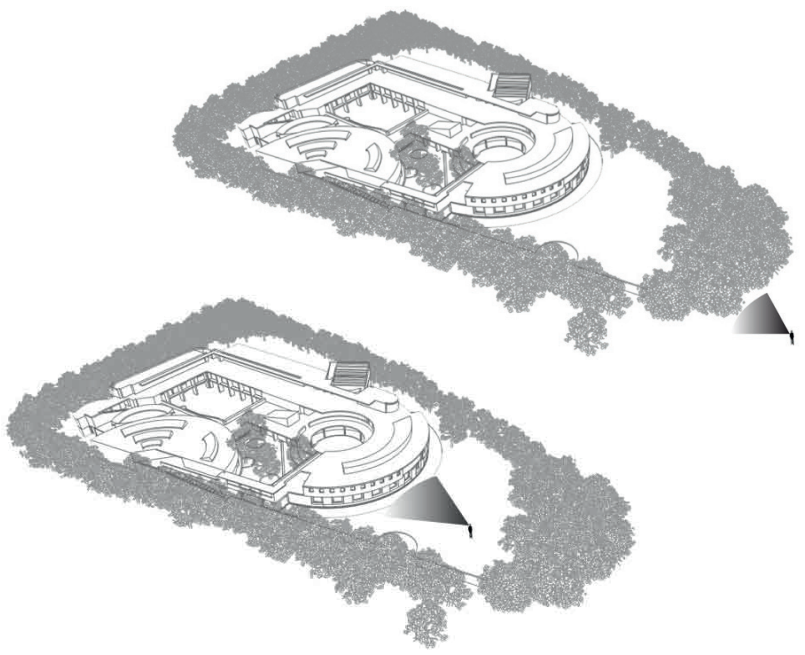

Fuente: el autor (análisis), Cristian Valencia (redibujo), 2016.

Previo al acceso principal se encuentra una escalera sobre un costado del edificio, anunciando el ascenso al nivel superior. El acceso presenta dos vestíbulos, uno abierto seguido de uno cubierto, el primero de estos, un patio con una continuidad material y perceptiva por el punto de ingreso definido por un puente, desde allí el recorrido se hace en diagonal y en ascenso, acompañado por dos atarjeas paralelas que conecta a un espejo de agua ubicado al inicio del acceso. En este espacio se encuentran árboles preexistentes al proyecto, uno de ellos marca la "puerta" del vestíbulo cubierto, además, se ubican jardines en el basamento de los muros que delimitan el patio. Por otra parte, el piso del patio se hace en adoquín perforado permitiendo el paso del césped sobre toda la superficie, a excepción del recorrido en diagonal (ver imágenes de la 32 a la 34).

Como se mencionó anteriormente, el acceso continúa con el vestíbulo cubierto en el que se mantiene una relación controlada hacia el cielo mediante una apertura cenital. En este espacio se continúa con el ascenso mediante una escalera y una rampa.

En el vestíbulo cubierto inicia el tránsito del proyecto, a partir de allí tendrá distintos reco-
Imágenes 32, 33 y 34. Edificio de Posgrados - Rogelio Salmona. Errancia - acceso.

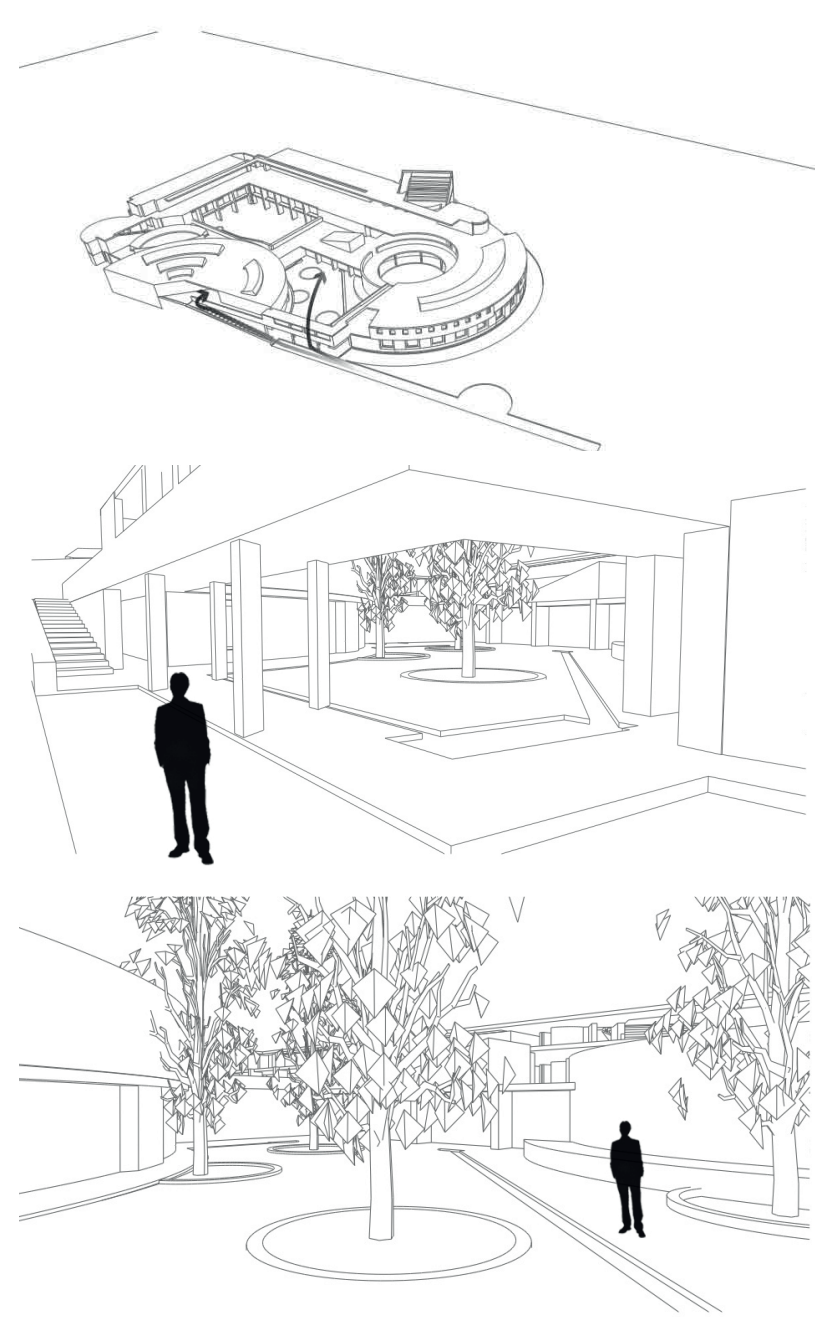

Fuente: el autor (análisis), Cristian Valencia (redibujo), 2016.

rridos para ir en ascenso hacia el último nivel del proyecto (cubierta). El tránsito toma distancia de convertirse en un recorrido único y secuencial del proyecto.

A diferencia de esto, el tránsito del proyecto se hace de forma horizontal y vertical, la estructura de la composición -por partes- permite que cada parte mantenga su propia autonomía. Para esto, además del espacio cubierto o descubierto que contenga, está definido por un recorrido, dicho recorrido para cada pieza permite estructurar múltiples recorridos en el proyecto, recorridos formalizados y recorridos aleatorios, recorridos horizontales y 
Imágenes 35, 36 y 37. Edificio de Posgrados - Rogelio Salmona. Errancia - Recinto circular - parte autónoma narrativa perceptiva.
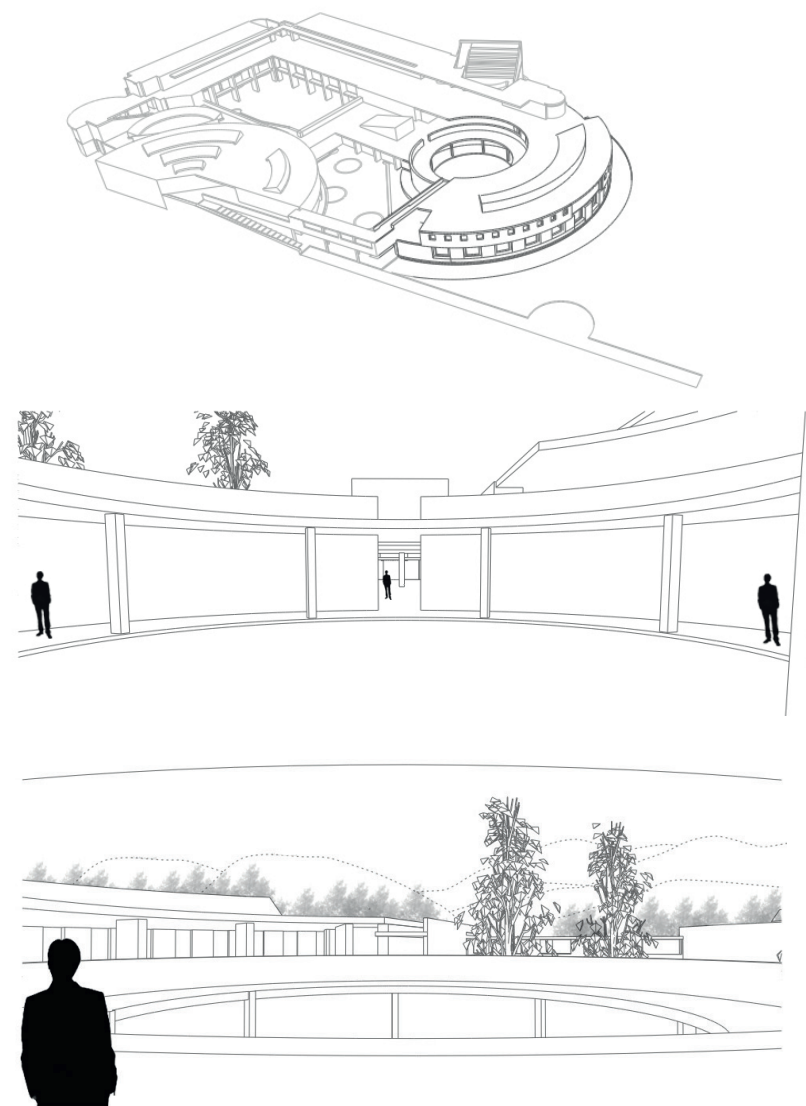

Fuente: el autor (análisis), Cristian Valencia (redibujo), 2016.

recorridos verticales, recorridos en acenso y en descenso. En el tránsito de los distintos espacios se contempla la naturaleza, ahora transformada en paisaje: los cerros, el cielo, espejos de agua, entre otros (ver imágenes de la 35 a la 40).

No hay un culmen material en el proyecto, el culmen va más allá de lo material del sitio y de la relación que establece con el paisaje. La errancia, re-crea el sitio, garantía de esto se da con la orientación del teatrino exterior dirigido hacia el oriente, por donde sale sol. En cuanto a la re-creación de lugares, lo hace con los cerros orientales de Bogotá, Monserrate y Guadalupe, lugares que hacen parte de la memoria de la ciudad.

Ahora bien, con respecto a la marche, promenade architecturale, errancia arquitectónica, en relación
Imágenes 38, 39 y 40. Edificio de Posgrados - Rogelio Salmona. Errancia - Recinto rectangular - parte autónoma narrativa perceptiva.
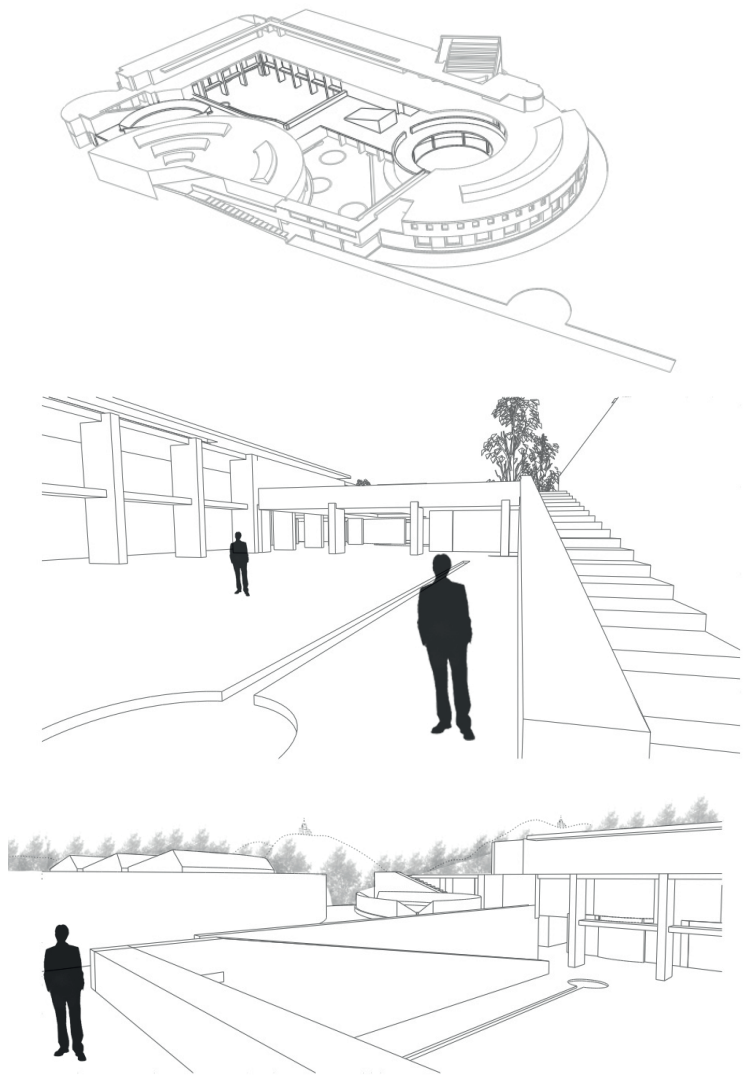

Fuente: el autor (análisis), Cristian Valencia (redibujo), 2016.

con la formalización de la naturaleza a paisaje, si bien se soportan en una narración secuencial, cada una presenta distintas características.

La marche, establece una vivencia del espacio interior, la ciudad se anula para contemplar el paisaje constituido por el jardín y por la percepción del cielo mediante los recintos. En el recorrido arquitectónico, cada una de las partes autónomas -recintos-dependen entre sí, cada una en relación con la que le precede, se mantienen encadenadas con una secuencia lógica que la condiciona, en orden: lo público, lo privado y lo íntimo.

La marche, puede comprenderse como una estructura conformada por distintas partes, relacionadas en un espacio central: el impluvium, un recinto en el que se recoge la lluvia para materializar un espejo 
de agua; el Tetrastile, espacio definido por cuatro columnas; y el viridarium en el que se deambula entorno al jardín. Los tres espacios constituyen partes autónomas, caracterizadas por ser espacios recintos delimitados horizontalmente y con una relación hacia el cielo.

Por su parte, la promenade architectural está compuesta por partes autónomas relacionadas entre sí, por el recorrido arquitectónico. No obstante, el proyecto advierte un recorrido paralelo a través de una escalera, que si bien no es ritual, hace desaparecer la secuencia. Esta lógica hace tomar distancia de la marche, en la medida en que ninguna parte depende de una anterior.

La única secuencia que se puede establecer, es su desarrollo en ascenso, de esta manera se tiene un contacto con la tierra antes de ingresar a la casa, esto gracias a la aproximación y al acceso. En un segundo acto, se anula la relación en el primer piso con el paisaje, seguido, la relación con el contexto inmediato, se reincorpora en el "jardín suspendido", espacio desde el que se enmarca el bosque que delimita el proyecto. Finalmente, se asciende y el culmen del proyecto finaliza en un solárium delimitado por cuatro jardines, similar al vestíbulo de cuatro columnas del primer nivel. Ante aquel solárium el bosque inmediato, de nuevo es delimitado por un vano, aquí el sitio se recrea.

En cuanto a la errancia arquitectónica, si bien está constituida por partes autónomas, al igual que las dos anteriores, su evolución está dada en que cada parte autónoma, a su vez mantiene un recorrido, de esta manera se genera un recorrido no secuencial, diferente a los dos trayectos anteriores. Por otra parte, a diferencia de la marche, que anula al sitio; y, con contraste a la promenade architectural, que se relaciona con el sitio, la errancia, se relaciona con lugares, producto de otras arquitecturas. Es así como la errancia, re-crea el sitio, garantía de esto se da con la orientación del teatrino exterior dirigido hacia el oriente, por donde sale sol; en cuanto a la re-creación de lugares, lo hace con Monserrate y Guadalupe, lugares que hacen parte de la memoria de la ciudad.

\section{Representacional y ontológico: un tránsito entre lo oculto y lo revelado}

El análisis permitió establecer que la relación entre la arquitectura y el paisaje es de carácter interno. No obstante, algunas relaciones son consideradas desde campos externos, fijan la atención en lo físico y real. Esta última posición conlleva a que proyecto y naturaleza se mixtifiquen ${ }^{6}$ y con ello surja una relación aparentemente verdadera. Estas respuestas son fundamentadas, en parte, desde los procesos del hacer y el fabricar, como la ciencia, que efectivamente remite a una verdad desde lo susceptible de análisis.

Por último, la neurociencia cognitiva permite a Luis De Garrido conocer los mecanismos neurobiológicos del dolor, de las emociones y de la consciencia, lo que le ayuda a conocer los mecanismos básicos del reconocimiento de la belleza y de la felicidad. Y por ello puede asegurar el éxito de sus diseños (Garrido, 2016).

La ciencia como mediadora entre la naturaleza y el arte, podría ser confirmada sin lugar a dudas mediante procesos tangibles y medibles, no obstante se trataría de una verdad ya establecida ${ }^{7}$ y su comprobación dada mediante los resultados del hacer y el fabricar, resultados que tempranamente se agotarían. Parte de estos procesos, ya se encuentran en catalogaciones contemporáneas con facilidades descriptivas asequibles al

6 En cuanto a este aspecto, otras respuestas en la relación entre arte y naturaleza optan por una solución netamente aparente. [...] La arquitectura, de este modo, se pone al lado de la naturaleza -y de su lado-, es decir, se com-pone con ella pero no la mixtifica. [...] Y cuando se pretende que algunas o todas estas cosas ocurran, entonces se mixtifica la naturaleza, se incurre en naturalismo y la arquitectura falla respecto a la esencia de su utilidad [...] (Armesto, 2000, p. 35).

7 "Frente a esto, la ciencia no es ningún tipo de acontecimiento originario de la verdad, sino siempre la construcción de un ámbito de la verdad, ya abierto, por medio de la fundamentación y la aprehensión de aquello que se muestra exacto dentro de su círculo de un modo posible y necesario" (Heidegger, 1935/2010, p. 45). 
entendimiento de las comunidades en las que son insertas, entre ellas y a saber, el vitalismo (facción gastronoia) un desarrollo que asimila el ciclo metabólico del cuerpo; la toponimia, soportada en la apariencia rigurosa de la realidad del sitio en el que se adhieren; la tectónia, masas fisiológicas producto de la extensión de la naturaleza (Armesto, 2000). Estas maneras de establecer relaciones, lo más severamente posible con la naturaleza, devienen del afán por incluir a la comunidad en la compresión de la arquitectura. Un paso que llevo a la síntesis de la arquitectura en escenografía (Frampton, 2002).

Más allá de establecer un símbolo como imagen directa a partir de la que iniciaría el discernimiento de la arquitectura; Kenneth Frampton (2002) propone retomar la condición tectónica sustentada en lo representacional y en su connotación ontológica, una ambivalencia que retoma de las distinciones que hace Semper entre lo estructuralsimbólico y lo estructural-técnico y que va a comprender, en orden, como "[...] la diferencia entre la piel que representa el carácter compuesto de la construcción, y el núcleo o tectónica de un edificio, que es su estructura fundamental y su sustancia a un mismo tiempo" (Frampton, 1999, p. 26). Esta dualidad de la tectónica, entre lo representacional y lo ontológico se revelan y ocultan alternativamente (Frampton, 1999, p. 26), una característica soportada en los planteamientos de Martín Heidegger en torno al carácter de la obra, entre la lucha de la tierra y el mundo.

La realidad de la obra ha sido determinada a partir de aquello que obra en la obra, a partir del acontecimiento de la verdad. Pensamos este acontecimiento como la disputa del combate entre el mundo y la tierra (Heidegger, 2010, p. 41).

El combate entre la tierra y el mundo, más allá de comprenderse como entidades materiales específicas, se manifiestan como el movimiento entre lo oculto y la revelación. Partiendo del planteamiento de Frampton, en relación con el de Martin Heidegger, se puede llegar a establecer lo repre- sentacional como aquella aparición que se oculta en sí misma, y por ende la necesidad de llevarla a lo abierto; en tanto que lo ontológico como aquello abierto que se encuentra retraído y que surge mediante el acontecimiento de lo oculto. $\mathrm{Al}$ igual que el combate entre la tierra y el mundo, lo representacional y lo ontológico, se complementan confirmando cada uno su esencia.

La dualidad de la condición tectónica de la arquitectura, se manifiesta en los proyectos anteriormente analizados, y con ello la revelación de la esencia oculta. Además de lo representacional de los elementos constructivos que están presentes en la materialización del proyecto arquitectónico, debe considerarse lo ontológico de la obra arquitectónica. "No hace falta decir, que no se alude aquí a la revelación de la construcción mecánica, sino más bien una manifestación potencialmente poética de la estructura en el sentido griego original de poiesis como un acto de hacer y revelador"8 (Frampton, 2002, p. 92). La materialización de la arquitectura sucede tras una esencia, no es el acto del hacer por el hacer, ni el de fabricar por el fabricar. Además del fin externo, como utilidad, debe establecerse la arquitectura a partir de un fin interno, un tránsito del no ser, al ser, en palabras de Martin Heidegger.

[...] La técnica no es pues un mero medio, la técnica es un modo del salir de lo oculto. Si prestamos atención a esto se nos abrirá una región totalmente distinta para la esencia de la técnica. Es la región del desocultamiento, es

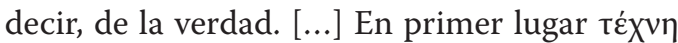
no sólo es el nombre para el hacer y el saber hacer del obrero manual sino también para el arte, en el sentido elevado, y para las bellas

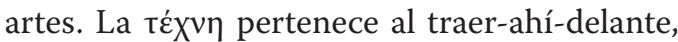

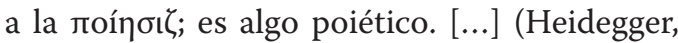
2001, p. 14).

La arquitectura considera la tectónica, y con ella, la "téchne" que hace parte de la poiesis, entendida

8 "Needless to say, we are not alluding here to mechanical revelation of construction but rather to a potentially poetic manifestation of structure in the original Greek sense of poesis as an act of making and revealing" (Frampton, 2002, p. 92). 
como el acto de producir, en el sentido de "traerahí-delante". Esto se puede ver en los proyectos analizados, quienes consideran el acto poiético en la arquitectura, como afirma Corbusier (1978) "La circulación procura unas impresiones arquitectónicas de una diversidad que desconcierta a todo visitante extraño a las libertades arquitectónicas aportadas por las técnicas modernas" (p. 158) y complementa Salmona (2006) "La arquitectura como acto poético va más allá del hecho constructivo. Al traspasar el hecho constructivo la arquitectura produce emoción [...]" (p. 50).

La marche, la promenade architectural, la errancia arquitectónica; son relaciones de la formas arquitectónicas que establecen relaciones entre sus distintas partes mediante lo oculto en cada una de ellas, a saber, la apertura mediante lo que se revela algo (Heidegger, 2010), para este caso, el paisaje, que acontece en alternancia entre lo oculto y la revelación.

La relación entre arquitectura y paisaje está conformada por la dialéctica interna de la obra arquitectónica, en la que se pone de manifiesto un fin interno. El objeto arquitectónico debe considerar aquel componente poético, que no es otra cosa que la constitución ontológica de la arquitectura.

\section{Conclusiones: percibir la realidad: contemplar la esencia}

La respuesta al problema entre la arquitectura y el paisaje se soporta en la forma y en la obra arquitectónica. Una vez analizados los objetos arquitectónicos, en cuanto a la forma arquitectónica, se realizó la distinción de relaciones y partes constitutivas. En cuanto a la obra arquitectónica, se sometieron las cuestiones de su constitución a juicios.

Ahora bien, el análisis de la forma, dio cuenta de tres relaciones: la marche, la promenade architecturale y la errancia. En referencia a la marche, se identificaron partes autónomas relacionadas entre sí por una estructura narrativa secuencial. Por su parte, la promenade architecturale mantiene la misma estructura de relación de la marche, además de considerar un recorrido paralelo no secuencial. Por otro lado, la errancia, además de tener en consideración las estructuras formales de la marche y la promenade architectural se constituye por partes autónomas, cada una manteniendo una estructura narrativa secuencial.

En cuanto a la relación entre la arquitectura y el paisaje, esta se da en el momento en que la arquitectura establece como uno de sus fines internos el acontecimiento mediante el cual se revela el paisaje. Ese fin interno, que no es el único de la obra, permite a su vez comprender de qué manera la arquitectura acontece como obra de arte. En la marche se anula el exterior y la vivencia del espacio interior se hace mediante la contemplación del jardín. En la promenade architecturale, además del jardín interior, se contempla el sitio mediante su re-creación, el sitio ya no es extraño, ahora es un lugar. En la errancia, además de contemplar el jardín y el sitio como sucede en la promenade architecturale, se contemplan lugares mediante su re-creación, aquí el lugar ahora es memoria para quien lo contempla.

La arquitectura precisa partir de una idea alétheia-, no preestablecida, en el sentido poiético de "traer-ahí-delante". Aquella idea permanece abierta durante el origen, desarrollo y posterior crítica de la arquitectura. Durante este tránsito,

Imagen 41. Archivo General de la Nación - Rogelio Salmona.

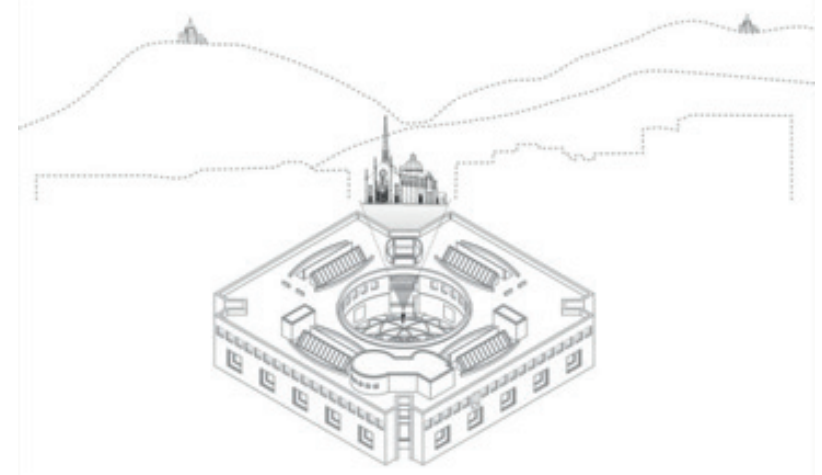

Fuente: el autor (análisis), Hugo Martínez (Redibujo) 2016. 
la obra arquitectónica es quien establece la relación entre los procedimientos intelectuales de la forma arquitectónica. Luego, aquella alétheia latente en lo representacional para ser revelada mediante la contemplación ontológica de la obra arquitectónica. La arquitectura, además de un acto de hacer y de fabricación, debe considerar el acontecimiento poiético para instaurarse como obra de arte.

\section{Referencias bibliográficas}

Abalos, I. (2005). Atlas pintoresco. Vol. 1: el observatorio. Barcelona, España: Editorial Gustavo Gili, SA.

Arendt, H. (2009). La condición humana. Buenos Aires: Paidós.

Argan, G.C. (1984). El concepto del espacio arquitectónico, desde el Barroco a nuestros días. Buenos Aires: Ediciones Nueva Visión.

Armesto, A. (2000). Arquitectura y naturaleza. Tres sospechas sobre el próximo milenio. Revista DPA 16 , pp. 34-43.

Escorcia, O. (2010). Manual para la investigación. Guía para la formulación, desarrollo y divulgación de proyectos. Bogotá: Universidad Nacional de Colombia.

Ching, F. (2002). Forma, espacio y orden. Barcelona: Editorial Gustavo Gili.

Correal, G.D., Francesconi, R., Rojas, P., Elígio, C.A., Quiroga, E., Páez, A., \& Salinas, Á.M. (2015). Aprendizaje, composición y emplazamiento en el proyecto de arquitectura. Un diálogo entre las aproximaciones analógica y tipológica. Bogotá: Universidad Católica de Colombia.

Frampton, K. (2012). El estatus del hombre y el estatus de sus objetos. En: K. Frampton, Kenneth Frampton (pp. 65-103). Pamplona. España: T6) ediciones. Escuela Técnica Superior de Arquitectura. Universidad de Navarra.

Frampton, K. (2002). Rappel à l'Ordre: The Case for the Tectonic. En: K. Frampton, Labour, work and Architecture: Collected Essays on Architecture and Design (pp. 91-103). London: Phaidon Press Limited.

Frampton, K. (1999). Estudios sobre cultura tectónica: poéticas de la construcción en la arquitectura de los siglos XIX y XX. Madrid: Ediciones Akal, S.A.

Garrido, L.D. (2016). Neurociencia Cognitiva de Luis De Garrido. Recuperado de: [https://goo.gl/tqdlg]].

Heidegger, M. (2010). El origen de la obra de arte (1935). En: M. Heidegger, Caminos de Bosque (pp. 11-62). Madrid, España: Alianza Editorial.

Heidegger, M. (2001). La pregunta por la técnica. En M. Heidegger, Martin Heidegger. Conferencia y artículos. (pp. 9-32). Barcelona, España: Ediciones del Serbal.

Le Corbusier. (1937). Oeuvre Complète 1910-1929.

Le Corbusier. (1949). Casa Curutche, memoria descriptiva. Tecnne / Arquitectura y texto. Recuperado de: [http://goo.gl/jjlo75].

Le Corbusier (1978). Precisiones respecto a un estado actual de la arquitectura y el urbanismo. Buenos aires: Poseidón.

Loos, A. (1993). Arquitectura (1910). En: A. Loos, Adolf Loos. Escritos II 1910 - 1931 (pp. 23-35). Madrid: El croquis editorial.

Quetglas, J. (2004). Promenade Architecturale. En J. Quetglas, Artículos de ocasión. Josep Quetglas (pp. 205-209). Barcelona-España: Editorial Gustavo Gili, S.A. Salmona, R. (2006). Espacios abietos / espacios colectivos. Bogotá, D.C.: Panamericana Formas e Impresos S. A. 